\title{
Growth promotants in feeding pigs and poultry. I. Growth and feed efficiency responses to antibiotic growth promotants
}

\author{
Sigvard Thomke*, Klas Elwinger \\ Department of Animal Nutrition and Management, Sweden Univ. Agric. Science, \\ P.O. Box 7024, S-750 07 Uppsala, Sweden
}

(Received 2 December 1997; accepted 5 January 1998)

\begin{abstract}
Since the beginning of the 1950s, growth promoters of antibiotic type have played a major role in the development of intensive and industrialised animal farming systems. The incorporation of such growth promoters into animal feed mixtures has made it possible to improve animal health conditions as well as to increase rearing intensity. Simultaneously, the admixing of these additives has successively lowered food production costs, a development which has been to the benefit of the consumer. The objective of this contribution was to review recent developments in this area and in particular to address growth promoters of antibiotic type authorised in the European Union as additives for pig and poultry. Finally, we also briefly touch upon the potential economic consequences of terminating their use under current European conditions, as well as their potential environmental effects. (O Elsevier / Inra)
\end{abstract}

growth promoter / antibiotic / pig / poultry

Résumé - Les promoteurs de croissance dans l'alimentation des porcs et des volailles. I. Réponses en terme de croissance et d'indice de consommation à l'addition d'antibiotiques. Les promoteurs de croissance, tels les antibiotiques, ont joué un rôle important durant ces dernières décennies dans le développement des systèmes d'élevage intensif et industriel. Leur incorporation dans l'alimentation animale a permis d'améliorer les conditions sanitaires des animaux et d'accroître la productivité des élevages, tout en diminuant simultanément les coûts de production. L'objectif de cet article est de passer en revue les connaissances nouvellement acquises dans ce domaine, et de s'intéresser plus particulièrement aux antibiotiques autorisés dans l'Union Européenne et utilisés dans l'alimentation des porcs et des volailles. Sont également évoqués les conséquences économiques de leur retrait dans le contexte européen actuel et leurs effets potentiels sur l'environnement. (C) Elsevier/Inra)

promoteur de croissance / antibiotique / porc / volaille

* Correspondence and reprints

Tel.: (46) 018671000 ; fax: (46) 018672995 


\section{INTRODUCTION}

The general benefits of using antibiotic growth promotants in livestock production are lower production costs leading to lower market prices and a more plentiful supply of food commodities. For the consumer, the direct benefits are lowered food prices [9]. However, there is growing concern among consumers in many countries about the use of growth promotants $[2,4$, $27,30,33]$. The background for this concern is found in the risks for the occurrence of residues of additives in animal food products, the development of resistance of pathogenic microorganisms in animals against antibiotic preparations, and the transfer of such germ plasma to human pathogenic microorganisms. The more reluctant attitude prevailing in the USA to a withdrawal of antibiotic promotants in livestock feeding is exemplified by the comprehensive review given by DuPont and Steele [11].

\section{LIVESTOCK PRODUCTION}

Livestock production is the result of an integrated approach of selection, nutrition, housing and health care [16]. Over the centuries there has been a gradual improvement in the efficiency of livestock production. This development has accelerated during recent decaldes by the introduction of more scientifically approved methods in the different areas of livestock production and by continuously implementing research findings in practice. Scientific contributions in the fields of animal physiology, genetics and nutrition as well as veterinary sciences and housing engineering were of great importance for the development of industrialized livestock production systems. By these means, man's ability to control and manipulate animal production increased tremendously after World War II. For the further development of livestock production systems in the future, one may expect the scientific fields of immunology and ethology to become of increasing importance.

In the development of intensive and industrialized livestock production during recent decades, antibiotic growth promotants, introduced in the early 1950s, have played a decisive role. Responses to growth promotants, and hence return to the farmer, will generally be maximized by keeping target animals healthy and providing them with adequate levels of nutrients and an appropriately balanced diet [30]. There is a variety of feed additives with growth promoting effects under discussion and, according to Laming [26], these can be categorized as follows:

- anabolic agents with the aim to alter nutrient partitioning, i.e., to increase protein deposition and yield of edible cuts;

- antimicrobial agents as to improve growth rate and feed efficiency and/or to prevent decreased growth rate in occurrence of disease; probiotics and acidifiers may be mentioned under this category;

- immunological methods to enhance growth rate or to improve carcass composition;

- $\beta$-adrenergic agonists to modify carcass composition by altering nutrient partitioning and lowering fat deposition, simultaneously increasing protein accretion.

Apart from these additives, a more detailed understanding of the mechanisms in the hypothalamic-pituitary endocrinal control of growth and metabolism could in the future lead to other means of improvements in animal production processes.

The term growth promotant is used for feed additives, other than dietary nutrients, which increase growth rate and/or improve feed efficiency in healthy animals, fed a balanced diet (Macgregor (1983) cited in 19]). According to the literature review by De Craene and Viaene [9] and as mentioned in CEAS et al. [7], 
there is a great variation in responses of animals to antibiotic growth promotants according to different authors (table I).

Thus, one of the entries for growingfinishing pigs claims a response in growth rate of up to $20 \%$, whereas for feed efficiency the lowest response was limited to $0.7 \%$. Furthermore, in judging these promoting effects one has to consider age and class of animals and also the duration of feed additive administration as well as the performance level of the control treatment group. In comparing effects of admixing 'antibiotic additives' over time, one has also to consider the change from more potent and medical preparations to other types, approved only as feed additives. The values by CEAS et al. [7] are obviously regarded in the EU as useful for general calculations.

\section{ANTIBIOTIC GROWTH PROMOTANTS IN USE IN THE EU}

The antimicrobial preparations act either bactericidally (e.g., penicillin) or bacteriostatically (e.g., tetracyclines). There is a third group of antimicrobial

Table I. Percentage of responses in growth performance and feed efficiency as a result of supplementing antibiotic promotants in livestock production compared with unsupplemented control diets as reported by different authors [7,9].

\begin{tabular}{|c|c|c|}
\hline & Growth, daily weight gain & Feed efficiency \\
\hline \multicolumn{3}{|l|}{ Piglets } \\
\hline CEAS et al. [7] & 16 & 9 \\
\hline \multicolumn{3}{|l|}{ Growing pigs $(20-50 \mathrm{~kg})$} \\
\hline CEAS et al. [7] & 9 & 5.5 \\
\hline \multicolumn{3}{|l|}{ Finishing pigs (50 kg-slaughter) } \\
\hline CEAS et al. [7] & 0 & 0 \\
\hline \multicolumn{3}{|l|}{ Growing-finishing pigs } \\
\hline Bickel $(1983)^{a}$ & $5-10$ & $5-7$ \\
\hline Hudd [23] & $4-5$ & $4-5$ \\
\hline Mordenti et al. (1979) a & 6.5 & 4.1 \\
\hline Weiss $(1989)^{\mathrm{a}}$ & $1.9-8.6$ & $0.7-5.1$ \\
\hline Robinson $(1969)^{a}$ & $10-20$ & $5-10$ \\
\hline CEAS et al. [7] & 3.5 & 3 \\
\hline \multicolumn{3}{|l|}{ Broiler chickens } \\
\hline Birzer and Gropp (1991) ${ }^{\mathrm{a}}$ & 4 & 4 \\
\hline Hudd [23] & $3-4$ & $3-4$ \\
\hline Mordenti et al. ( 1979$)^{a}$ & 5.0 & 3.5 \\
\hline Robinson $(1969)^{\mathrm{i}}$ & $5-10$ & 5 \\
\hline CEAS et al. [7] & 4 & 4 \\
\hline CEAS et al. [7] laying hen performance & 2 & 1 \\
\hline \multicolumn{3}{|l|}{ Veal calves } \\
\hline Birzer and Gropp (1991) & 10 & 5 \\
\hline CEAS et al. [7] & 7 & 4 \\
\hline
\end{tabular}

"Cited in $|9|$. 
additives, ionophores, which also control protozoal growth. These preparations are of particular interest as additives for ruminants and poultry.

The antibiotic growth promotants approved in the EU are listed in table II. A brief description of their chemical and microbial properties is given by, e.g., Hudd [23]. The approval of the individual promotants is linked to minimum and maximum levels of inclusion in the target diets. The level of supplementation of a certain promotant may vary between animal species and also between classes. Moreover, the levels of supplementation may be regulated for the different stages of development and to a maximum age of animals. The use of carbadox and olaquindox supplemented diets has to be discontinued not later than 4 weeks prior to slaughter. According to the potential of the additive, the dose of active ingredient may vary between 1 and 100 ppm (mg per $\mathrm{kg}$ ) in the target diet.

Table II. Antibiotic growth promotants approved in the EU (Council Directive 70/524/EEC, cf. SOU [43]).

\begin{tabular}{|c|c|c|c|c|c|}
\hline \multirow[b]{2}{*}{ Additive } & \multirow{2}{*}{$\begin{array}{l}\text { Animal } \\
\text { species/ } \\
\text { class }\end{array}$} & \multirow{2}{*}{$\begin{array}{l}\text { Maximum } \\
\text { age }\end{array}$} & \multicolumn{2}{|c|}{ Level of inclusion $\left(\mathrm{g} / \mathrm{kg}^{\mathrm{a}}\right)$} & \multirow{2}{*}{$\begin{array}{l}\text { Withdrawal } \\
\text { time prior to } \\
\text { slaughter }\end{array}$} \\
\hline & & & $\min$. & $\max$. & \\
\hline \multicolumn{6}{|c|}{ Antibiotic growth promotants } \\
\hline \multirow[t]{3}{*}{ Avilamycin } & $\mathrm{Pi}$ & $4 \mathrm{mo}$ & 20) & 40 & \\
\hline & GFP & $4-6 \mathrm{mo}$ & 20 & 20 & \\
\hline & Po & & 2.5 & 10 & \\
\hline \multirow[t]{4}{*}{ Flavophospholipol } & $\mathrm{C}$ & $6 \mathrm{mo}$ & 6 & 16 & \\
\hline & GFP & $6 \mathrm{mo}$ & I & 20 & \\
\hline & Po & 16 weeks & 1 & 20 & \\
\hline & $\mathrm{BCa}$ & & 2 & 10 & \\
\hline Monensin- $\mathrm{Na}$ & $\mathrm{BCa}$ & $4 \mathrm{mo}$ & 10 & 40 & \\
\hline \multirow[t]{2}{*}{ Salinomycin-Na } & $\mathrm{Pi}$ & $4 \mathrm{mo}$ & 30) & 60 & \\
\hline & GFP & $6 \mathrm{mo}$ & 15 & 30 & \\
\hline \multirow[t]{2}{*}{ Spiramycin ${ }^{b}$} & $\mathrm{C}$ & $6 \mathrm{mo}$ & 5 & 20 & \\
\hline & GFP & $6 \mathrm{mo}$ & 5 & 20 & \\
\hline \multirow[t]{2}{*}{ Tylosinphosphate } & $\mathrm{Pi}$ & $4 \mathrm{mo}$ & 10) & 40 & \\
\hline & GFP & $6 \mathrm{mo}$ & 5 & 20 & \\
\hline \multirow[t]{3}{*}{ Virginiamycin } & $\mathrm{C}$ & 16 weeks & 5 & 20 & \\
\hline & GFP & $6 \mathrm{mo}$ & 5 & 20 & \\
\hline & Po & & 5 & 20 & \\
\hline \multirow[t]{3}{*}{ Zn-bacitracin ${ }^{b}$} & $\mathrm{C}$ & $6 \mathrm{mo}$ & 5 & 20 & \\
\hline & GFP & $6 \mathrm{mo}$ & 5 & 20 & \\
\hline & Po & 16 weeks & 5 & 20 & \\
\hline \multicolumn{6}{|c|}{ For therapeutical use } \\
\hline Carbadox & $\mathrm{Pi}$ & $4 \mathrm{mo}$ & 20 & 50 & 4 weeks \\
\hline \multirow[t]{2}{*}{ Olaquindox } & $\mathrm{Pi}$ & $4 \mathrm{mo}$ & 15 & 50 & 4 weeks \\
\hline & MR & $4 \mathrm{mo}$ & 50 & 100 & 4 weeks \\
\hline
\end{tabular}

C, calves; GFP, growing-finishing pigs; BCa, bef cattle; Pi, piglets; Po, poultry; MR, in milk replacers:

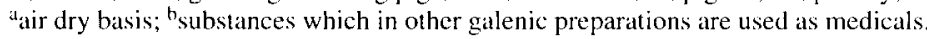




\section{GROWTH AND FEED EFFICIENCY RESPONSES TO PROMOTANTS IN PIGS}

The main interest in exploiting antibiotic growth promotants is in the sectors of pig and poultry production [36]. Since the 1950s there has been a strong development in the use of antibiotic promotants. The major part of the research in this area with different animal species has been performed within the manufacturing and feed industries, whereas a relatively limited part has been performed by independent research bodies [5].

Discrepancy exists concerning the effect of antibiotic promotants on sow performance. Speer [44] concluded that the farrowing rate was improved by the use of promotants. However, antibiotic promotants had no effects on oestrus, mating behaviour or breeding efficiency [31]. Litter weights at birth and at weaning were improved [42], which could not be corroborated by Frölich et al. [17] under Swedish conditions.

By testing different antibiotic growth promotants in sows, Frölich et al. [17] found the number of resistant $C$. perfringens strains in faecal samples to increase by supplementation with aureomycin, terramycin, oleandomycin or spiramycin, whereas such an increase was not observed by supplementing $\mathrm{Zn}$-bacitracin or virginiamycin.

The response of younger animals like piglets (as well as broiler chickens and calves) to promotants compared with unsupplemented diets is usually found to be superior compared with adolescent classes of these species. This is demonstrated for piglets, with growth responses to promotants between 9 and $30 \%$ and feed efficiency responses between 6 and $12 \%$, whereas for growing-finishing pigs the level of response is inferior (table III). The highest value given for piglets was obtained by Nousiainen and Suomi [32] by providing the promotant olaquindox in a water solution. These authors observed a significantly higher colonic digesta dry matter content in connection with promotant supplementation, which indicates better health and also explains the higher feed intake by the supplemented treatment group.

The response to withdrawal of olaquindox from 1986 on piglet health and performance in 220 Swedish piglet producing herds was statistically evaluated by Robertsson and Lundeheim [34] by using the Swedish efficiency monitoring system (RASP). Removal of olaquindox from the piglet diets was followed by a doubling of incidences of diarrhoea and number of medical treatments of diarrhoea postweaning as well as by an increased mortality by about 1.5 percentage units. On the withdrawal of olaquindox as growth promotant, the age at $25 \mathrm{~kg}$ increased by 5-6 days. In recent years the Animal Health Service control programs have further been developed with guidelines for practicing veterinarians and piglet producers, and measures have been taken to improve management, animal environment and feed composition, all of which have led to positive results in lowering the incidence or even preventing the occurrence of diarrhoea [34].

In addition to the information given in table III, the report by Tarrago et al. [45] should be quoted as the supplementation of tylosin as well as of virginiamycin resulted in significant improvements in piglet growth performance, but in nonsignificant improvement of feed efficiency.

This difference in responses between piglets and growing-finishing pigs is further illustrated by a comprehensive Yugoslavian study [48]. These authors investigated responses in piglets $(6-20 \mathrm{~kg}$ live weight) fed diets supplemented with either of four promotants and which were compared with unsupplemented control 
Table III. Growth performance (GP) and feed efficiency ratio (FER) responses of piglets and growing-finishing pigs in relation to unsupplemented control.

\begin{tabular}{|c|c|c|c|c|c|}
\hline & \multirow{2}{*}{$\begin{array}{l}\text { Growth } \\
\text { promotant }\end{array}$} & \multirow{2}{*}{$\begin{array}{c}\text { Weight } \\
\text { interval } \\
(\mathrm{kg})\end{array}$} & \multicolumn{2}{|c|}{ Effects on $(\%)$} & \multirow{2}{*}{ Comment } \\
\hline & & & GP & FER & \\
\hline \multicolumn{6}{|l|}{ Piglets } \\
\hline Gropp and Schultz (1973) & CADX & $16-29$ & 24.0 & 12.0 & \\
\hline Gropp et al. $(1991)^{a}$ & & & 16.0 & 9.0 & \\
\hline $\operatorname{Harp}(1987)^{\mathrm{a}}$ & & $7-26$ & 16.0 & 7.0 & \\
\hline Jongbloed $(1992)^{\mathrm{a}}$ & AVM & $8-25$ & 9.2 & 6.5 & \\
\hline Korniewicz et al. [24] & TYL & $5-23$ & 14 & 12 & \\
\hline Nousiainen and Suomi [32] & OLQ & $2-18$ & 30 & & prov. in water sol. \\
\hline Zivkovic and Zlatic [48] & & $6-20$ & $11-15$ & $5-10$ & 3 diff. promotants ${ }^{b}$ \\
\hline \multicolumn{6}{|l|}{ Growing-finishing pigs } \\
\hline \multirow[t]{2}{*}{ Beck and Gropp [3] } & PAYZ & $12-90$ & 2.7 & 2.8 & SPF animals \\
\hline & FLM & & 1.4 & 2.1 & SPF animals \\
\hline Bruckhard $(1984)^{\mathrm{a}}$ & & & 4.0 & 3.0 & \\
\hline \multirow[t]{2}{*}{ Cromwell $(1977)^{\mathrm{a}}$} & TYL & & & & \\
\hline & $\begin{array}{l}\text { Zn-bac } \\
\text { VIM }\end{array}$ & & 4.0 & 2.5 & \\
\hline \multirow[t]{2}{*}{ Cromwell et al. [8] } & $\mathrm{U}-82,127$ & $19-55$ & 3.9 & 3.2 & produced by \\
\hline & & $19-89$ & 3.5 & 2.8 & $\begin{array}{l}\text { Str. araginensis, } \\
5 \text { antimicrobials }\end{array}$ \\
\hline Decuypere et al. [10] & VIM & & 5.0 & 7.0 & \\
\hline Gropp and Gruber (1988) & diff. & $20-50$ & 8.8 & 6.0 & \\
\hline Gropp et al. $(1991)^{a}$ & & & 3.5 & 3.0 & \\
\hline Gropp and Schulz (1973) & & growers & 6.0 & 4.0 & \\
\hline Hellberg [21] & Zn-bac & $23-90$ & 0.7 & 1.3 & \\
\hline Jongbloed $(1992)^{\mathrm{a}}$ & TYL & $25-108$ & 3.3 & 4.3 & \\
\hline Lindermeyer et al. [29] & TYL & $26-100$ & 6.2 & 4.7 & \\
\hline Schneider [37] & TYL & $31-101$ & 3.1 & 4.2 & av. of 35 exp. \\
\hline \multirow{2}{*}{$\begin{array}{rr}\text { Schneider [38] } & 1974 \\
& 1985\end{array}$} & TYL & $31-101$ & 4.0 & 4.2 & \\
\hline & TYL & $30-102$ & 3.0 & 3.9 & \\
\hline Tidén [46] & Zn-bac & $22-100$ & -0.3 & -0.3 & no diff. in morb. \\
\hline Weiss $(1989)^{\mathrm{a}}$ & & & 4.3 & 2.9 & \\
\hline
\end{tabular}

${ }^{a}$ Cited in Verbeke and Viaene |47]; AVM, avilamycin; CADX, carbadox; FLM, flavomycin; PAYZ, payzon; TYL, tylosin-tylan; VIM, virginiamycin; Zn-bac, Zn-bacitracin; OLQ, olaquindox; 'one of the four treatments was excluded since it contained Aureo SP-125 (a mixture of chlortetracycline, sulfamethazine and penicillin); the variation given refers to the results for FLM, PAYZ, mecadox and $\mathrm{CuSO}_{4}$.

diets. One of these preparations, Aureo SP-125, was the most potent and was based on therapeutically used antibiotics (see footnote in table III). Therefore, the fourth treatment was excluded. For the remaining three promotants the growth responses varied between 10 and $15 \%$ and the feed efficiency responses between 5 and $10 \%$. Corresponding values for growing-finishing pigs $(20-90 \mathrm{~kg}$ ) fed diets supplemented with the same promotants varied between 5 and $8 \%$ (growth rate) and between 4 and $7 \%$ (feed efficiency), respectively.

Similarly, by comparing the promotant effect of tylan on daily weight gains in the 
growing phase with those in the finishing phase, Schneider [38] arrived at relative responses in growth rate of 4.7 and $2.4 \%$, respectively. For feed efficiency, corresponding improvements were found to be 9.1 and $2.8 \%$, respectively. Lindermeyer et al. [29] also reported higher responses in daily weight gains and feed efficiency in the growing phase $(20-50 \mathrm{~kg})$ of 13 and $15 \%$, respectively, versus 6 and $5 \%$ for the entire growing-finishing period.

Responses by growing-finishing pigs to the feeding of growth-promoting agents in the period from 1950 to 1984 were studied by Gruber [19]. The most effective group of growth promotants included streptomycin, penicillin and quinoxalines, whereas the least effective group included taomycin, salinomycin, nitrovin and the bacitracins. The results over time within the periods under study suggest a decreasing effect of growth promotants on daily weight gain and feed efficiency. A slight decrease in efficacy over time has also been reported by Rosen [35]. However, one has to consider the use of more potent preparations of therapeutical type in the beginning of this period compared with less potent ones in more recent times, such as the antibiotic promotants approved in the EU and listed in table II. When comparing tylan responses on growth rate and feed efficiency in growing-finishing pigs, Schneider [38] was unable to find differences in responses in the period of 1969/79 versus 1980/90 (table III). However, the trend of increasing the level of dietary promotants with time has to be considered $[27,35]$. Unfortunately, the report by Schneider [38] does not give any information on this issue. Moreover, the change over time in cost of promotants might influence their level of inclusion. Thus in the 25-year period 1967-93 the improvement in feed efficiency for broiler chickens needed to defray cost of, e.g., virginiamycin has decreased from 4.3 to only
$0.43 \%$ [35]. One would arrive at similar results in calculations on pigs.

In further commenting some entries in table III, the extensive body of experimentation by Schneider [37] should be mentioned, in which results from 35 German experiments with tylan performed in the period 1969 to 1990 with a total of 3800 pigs have been compiled. Information on the level of tylan inclusion is, however, not given. This author arrived at relative responses to tylan administration for average daily weight gains and feed efficiency of 3.1 and $4.2 \%$, respectively, compared with unsupplemented control diets.

By comparing some commercial diets without and with supplementation of antibiotics and fed to growing-finishing pigs kept under good environmental conditions, Hellberg [20] observed promoting effects on growth rate and feed efficiency of 3.4 and $1.9 \%$, respectively. In further studies, the promoting effects of $\mathrm{Zn}$-bacitracin were found to be 0.7 and $1.3 \%$, respectively [21]. A general opinion is that growth and feed efficiency responses of pigs and of broiler chickens to antibiotic promotants is lower under improved environmental conditions compared with poorer environments. Rosen [35] estimates the ratio in response between a very good and a poor environment to $1: 2$.

The main result of the data compiled in table III gives an average response by supplementation of piglet diets with antibiotic promotants in comparison with unsupplemented control diets for growth rate and feed efficiency of 17 and $9 \%$, respectively, which is the same value as given by CEAS et al. [7]. In comparison with piglets, corresponding responses for growing-finishing pigs were inferior and averaged 3.6 and $3.1 \%$ for growth rate and feed efficiency, respectively. These values are in good agreement with CEAS et al. [7], arriving at average values of 3.5 and $3.0 \%$. 
There are difficulties in predicting responses on performance in Swedish pig industry to a re-introduction of antibiotic growth promotants. As a result of changes in the country's animal welfare rules, the current rearing and production models and performance levels differ from those in the international experiments reviewed. Therefore, a lower response level on performance may be expected. In the piglet sector for growth performance and feed efficiency a response to antibiotic promotants of 4-5\% may be assumed. For growing-finishing pigs compared with piglets a lower level of responses to promotant additives of $1.5-2 \%$ may also be assumed.

\section{GROWTH AND FEED EFFICIENCY RESPONSES TG PROMOTANTS IN POULTRY}

As earlier outlined for pigs, there has been a strong development in the use of growth promotants in broiler chickens as well as in layers since the 1950s [5]. According to Garland [18], the financial advantage of feed costs by using antibiotic promotants in the UK broiler chicken industry may be calculated to be in the region of $0.035 \mathrm{ECU}$ per bird. On the basis of an annual production of 660 million birds, one arrives at an extra yield of 23100 tons of bird liveweight, and a saving of about 91000 tons feed, which equals a gross financial saving of 25 million ECU in the UK.

The main body of the experimental work on responses of broiler chickens with respect to administration of promotants demonstrates an effect in comparison with the unsupplemented control of between 99 and $106 \%$ [5]. In poultry as well as in pig production, the technique of shuttling every 6 th month between different growthpromoting preparations was introduced at an early stage in order to avoid adaptation of the microbial flora to a single promotant.

Swedish and Danish experiments, performed during the period of 1967-76 with broiler chickens fed Zn-bacitracin have been reviewed by Elwinger [12]. With the exception of one entry (in which the birds were kept in cages), the broiler chickens were raised in floor pens. The age at termination of the experiments varied between 36 and 56 days. The birds were fed diets supplemented with between 5 and $20 \mathrm{ppm}$ $\mathrm{Zn}$-bacitracin (in 11 entries). This supplement improved growth rate, on an average, by $2.0 \%$ and feed efficiency by $1.3 \%$ over the unsupplemented control diets. There were no differences in mortality.

In correspondence with the result for pigs, responses in broiler chickens to promotants gave growth rates and feed efficiencies that were superior in the first phase of development compared with the second. This is also in agreement with the situation in turkeys as reported by Küther [25]; table IV).

In a comprehensive review, Rosen [36] investigated the nutritional effects of tetracyclines (546 entries) and Zn-bacitracin (483 entries) in broiler chicken diets by using multi-factorial regression analysis. The model included dietary concentration of growth promotant, weight gain, feed efficiency, duration fed, gender, presence of disease and anticoccidial use. The results were also economically evaluated. Minimum levels of growth promotants have been calculated. Heavyweight birds responded better than lightweights. $\mathrm{Zn}$-bacitracin was superior to tetracyclines, mainly as a result of better feed conversion ratios and more limited variation in effects. At the supplementation level of $\mathrm{Zn}$-bacitracin presently recommended, and by using the models worked out by this author [36], one arrives at responses in growth rate and feed efficiency of 2 and $3 \%$, respectively. It was also observed that the promotants were 
Table IV. Growth performance (GP) and feed efficiency ratios (FER) of broiler chickens and turkeys in relation to unsupplemented control diets.

\begin{tabular}{|c|c|c|c|c|c|}
\hline & \multirow{2}{*}{$\begin{array}{l}\text { Growth } \\
\text { promotant }\end{array}$} & \multirow{2}{*}{$\begin{array}{c}\text { Age } \\
\text { interval, } \\
\text { days }\end{array}$} & \multicolumn{2}{|c|}{ Effect on $(\%)$} & \multirow{2}{*}{ Comment } \\
\hline & & & GP & FER & \\
\hline \multirow[t]{2}{*}{ Bartov [1] } & Zn-bac & $7-28$ & 2.3 & 0 & \multirow{3}{*}{$\begin{array}{l}\text { improved AME } \\
\text { decr. N-em. by } 5.2 \%\end{array}$} \\
\hline & VIM & & 2.2 & -3.3 & \\
\hline $2.5 \%$ & AVM & & 58 & 17 & \\
\hline Broz et al. [6] & VIM & $1-35$ & 1.8 & 3.4 & \multirow{6}{*}{$\begin{array}{l}\text { no diff. in mort., } \\
\text { impr. litter qual. } \\
\text { and foot health, } \\
\text { low. C.perfring. } \\
\text { as for AVM } \\
\text { no diff. in mort., } \\
\text { impr. foot health,low. } \\
\text { C. perfringens counts } \\
\text { as for AVM }\end{array}$} \\
\hline Cabrera et al. $(1993)^{\mathrm{a}}$ & Zn-bac & & 5.4 & 5.5 & \\
\hline Chol and Rya (1993) & Zn-bac & & 2.6 & 4.4 & \\
\hline Elwinger et al. [13] & AVM & $1-45$ & 4.4 & 4.5 & \\
\hline \multirow[t]{2}{*}{ Elwinger et al. [14] } & AVM & $1-43$ & 8.3 & 2.6 & \\
\hline & AVP & $1-43$ & 10.2 & 3.1 & \\
\hline Fonseca and Rostagno (1993) & $\mathrm{Zn}-\mathrm{bac}$ & & 6.0 & 4.7 & \\
\hline Hofshagen and Kaldhusdal [22] & AVP & $\begin{array}{l}1-28 \\
1-35\end{array}$ & 4.2 & 2.5 & \\
\hline Küther [25] & VIM & $\begin{array}{l}1-45 \\
1-45\end{array}$ & $\begin{array}{l}2.6 \\
5.8\end{array}$ & $\begin{array}{l}1.0 \\
4.2\end{array}$ & $\begin{array}{l}\text { av. } 5 \text { ref., low lev. } \\
\text { av. } 5 \text { ref., high lev.c }\end{array}$ \\
\hline Laczay et al. $(1993)^{\mathrm{a}}$ & $\mathrm{Zn}-\mathrm{bac}$ & & 5.6 & 5.2 & \\
\hline \multirow[t]{2}{*}{ Langhout and Schutte [28] } & AVM & $1-26$ & 2.6 & 1.8 & \\
\hline & VIM & $1-26$ & -0.2 & 1.3 & \\
\hline Schutte et al. [40] & VIM & $1-38$ & -0.8 & 1.5 & \\
\hline Schurz and Jeroch [39] & Zn-bac & $1-35$ & 5.0 & 0.5 & \\
\hline \multicolumn{6}{|l|}{ Turkey } \\
\hline \multirow[t]{4}{*}{ Küther [25] } & VIM & $1-12$ & 2.7 & 4.4 & \\
\hline & & $1-22$ & 1.8 & 0.4 & \\
\hline & AVP & $1-12$ & 1.8 & 4.5 & \\
\hline & & $1-22$ & 0.5 & 0.8 & \\
\hline
\end{tabular}

${ }^{\text {a }}$ Cited in Verbeke and Viaene [47]; AVM, avilamycin; AVP, avoparcin; VIM, virginiamycin; Zn-bac, Znbacitracin; AME, energy value; 'bow level starter diets containing 2-1 $10 \mathrm{ppm}$; grower diets $2.5-7.5 \mathrm{ppm}$; ${ }^{\mathrm{Chigh}}$ level starter diets containing $15-20 \mathrm{ppm}$; grower diets $5-15 \mathrm{ppm}$.

more effective with respect to live weight gains when used in diseased than in apparently healthy birds. By including anticoccidials the growth-promoting effect of the promotants themselves was clearly limited, depending on the fact that anticoccidials have a growth-promoting effect as well. As a general comment on this investigation, one should recognize that today's rec- ommended dosage for promotants has increased compared with when they were introduced. This increase in recommended dosage over time could be a result of decreasing cost per active unit and/or a way to keep disease level low.

As reported by Bartov [1] (see table $I V$ ), avilamycin supplementation improved 
the energy value (AME) over the unsupplemented control diet by $2.5 \%$. Recently, Schutte et al. [40] reported an improvement in the digestibility of gross energy, $\mathrm{N}, \mathrm{P}$ and amino acids for adult roosters as a result of supplementing a diet with 20 ppm virginiamycin.

As a beneficial effect in addition to growth promotion, the inclusion of promotants has often been reported to improve litter quality, which is a result of decreasing excreta moisture content $[13$, 14]. This may be regarded as an advantage for bird hygiene and health, but also improves labour and bird environment by decreasing $\mathrm{NH}_{3}$ formation and environmental air pollution as well [15].

The overall responses of broiler chickens to the promotants listed in table IV as regards growth rate and feed efficiency in comparison with unsupplemented control diets may be calculated to be, on average, 3.9 and $2.9 \%$, respectively. These mean values are in fairly good agreement with those given by CEAS et al. [7] of $4 \%$ for both traits. However, the value of $2 \%$ for growth rate based on Rosen [36] is much lower. This contrast could possibly be explained by zero and negative responses to promotants being noticed in a significant part of the experiments compiled by Rosen [35].

A re-introduction of antibiotic growth promotants into today's Swedish broiler chicken industry would certainly imply responses in performance and feed efficiency at a lower level than mentioned earlier. Explanations of this are that the Swedish broiler industry has introduced production models without the use of antibiotic promotants, with a very high standard of animal hygiene and by the use of feeding programmes including admixture of anticoccidials and enzyme preparations. A tentative response level for performance and feed efficiency of $1-1.5 \%$ may be assumed.

\section{ENVIRONMENTAL IMPLICATIONS OF FEEDING ANTIBIOTIC PROMOTANTS}

As reviewed previously, the feeding of antibiotic promotants improves pig and poultry growth rate and feed efficiency. The response in younger animals is superior to that of more adolescent individuals. The superior growth rate of animals means that the turn-over rate of a certain batch of animals is speeded up, leading to an economic advantage for promotant feeding. From an economic point of view, the improved feed efficiency is, however, of predominant importance.

As a consequence of the improved feed efficiency, the amounts of nutrients excreted by the animals as faeces and urine are lowered in proportion to the decreased amount of feed consumed by the animals, i.e., by approximately $3-4 \%$. For pig and poultry production based on cereal diets, this level corresponds to a relative decrease in nutrient discharge of 15-20\%. According to the present literature review on poultry and pigs, dietary administration of antibiotic promotants does not noticeably affect nutrient absorption. However, amino acid balances have been demonstrated to be improved in animals fed antibiotic promotants. On the other hand, any proteinsaving effects beyond the lowered amount of feed needed per bird have yet to be proven.

In poultry, antibiotic dietary inclusion has been shown to improve litter quality. Litter quality has also been shown to affect $\mathrm{NH}_{3}$-formation [15]. As a consequence, housing environment may be expected to be improved by antibiotic promotant feeding, which also leads to an impact for the external environment. With respect to the fact that ionophoric additives have effects similar to those of antibiotic promotants, one could speculate that the environmental effects mentioned are brought about by ionophores as well. 


\section{ECONOMIC IMPACT OF PROMOTANT WITHDRAWAL IN THE EU}

According to De Craene and Viaene [9] studying the economic effects of growth promotants for livestock production within the EU by model calculations at farm level, a withdrawal of antibiotic growth promotants would imply a rise in production costs of up to $8.2 \%$ for pig meat. On withdrawal, the pig meat price would rise and intra-Community trade would be affected. For the entire EU, exports would decrease, which would reduce expenditures on export refunds. In the pig meat sector, the annual reduction in economic benefits would amount to $1.21 * 10^{9} \mathrm{ECU}$, of which the consumers would have to bear $48 \%$ and the producers $52 \%$. The consumers would buy smaller quantities of higher priced meat products and would try to find substitutes. For poultry meat and eggs at farm level, production costs would increase by 3.4 and $1.2 \%$, respectively. The demand for eggs would decrease only slightly, but total loss of benefits in the EU would annually be $29 * 10^{6}$ ECU, of which the consumers would bear $70 \%$ and the producers $30 \%$. On withdrawal of promotants, broiler meat production is expected to increase by $3.4 \%$. In this sector, the annual economic benefits would decrease by $22910^{6} \mathrm{ECU}$, of which $57 \%$ have to be borne by the producers and $43 \%$ by the consumers.

Production costs for beef would increase by $6 \%$ and would be followed by a slight decrease in demand. Economic benefits would be lowered by $820 * 10^{6}$ ECU. In the dairy cattle sector, withdrawal of promotants is expected to increase production costs by $4.6 \%$. However, this increase would not affect demand. This would result in a forcing out of the less efficient farmers, their milk quotas being bought by more efficient farmers.
It might be stressed that these calculations are based on today's situation in the EU. Future changes in subsidy levels transferred to different sectors of EU agriculture will certainly have an impact on the outcome of this type of calculations.

\section{CONCLUSION}

Pig and poultry responses to dietary inclusion of antibiotic promotants in terms of growth performance and feed efficiency as compared with unsupplemented control diets are higher in the first phase than in the second phase of the growing period. Thus, piglets respond more clearly than growing pigs $(20-50 \mathrm{~kg}$ ), and these again respond more efficiently than finishing pigs ( $50 \mathrm{~kg}$ to slaughter). In the latter class of animals promotant effects seem to be minute. In poultry, promotant effects decline correspondingly. Responses to promotants of a specific type in recent time seem to be of the same magnitude as compared with 20 years ago, although for some preparations the recommended doses have increased. Obviously, antibiotic promotants decrease animal morbidity. The growth performance response of growingfinishing pigs and broiler chickens to promotant additives presently approved in the EU is 3 to $4 \%$ compared with unsupplemented control diets. For feed efficiency in pigs, as well as in poultry meat production, the values are slightly lower. The relative responses to antibiotic promotants are lower under good environmental conditions than under poor. From an economic point of view, responses in feed efficiency are of greater importance than growth performance. Promotant dietary inclusion also leads to improvements (labour and external) through lower excreta nutrient discharges in pigs and poultry, and probably also lower $\mathrm{NH}_{3}$ formation in poultry litter. 


\section{ACKNOWLEDGMENTS}

This review was published in the journal of the Royal Swedish Academy of Agriculture and Forestry 136 (19) (1997) 9-21. Permission to reprint it was kindly granted by the Royal Swedish Academy of Agriculture and Forestry.

\section{REFERENCES}

[1] Bartov I., Effect of growth promoters on monensin toxicity in broiler chicks, Br. Poultry Sci. 35 (1994) 123-133.

[2] Bates J., Jordens J.Z., Griffiths D.T., Farm animals as putative reservoir for vancomycinresistant enterococcal infection in man, $\mathrm{J}$. Antimicrob. Chemother. 34 (1994) 507-514.

[3] Beck H., Gropp J., Payzone bei SPFSchweinen, Landwirtschaftl. Forsch. 28 (1973) 25-30.

[4] Begley S., The end of antibiotics, Newsweek The International, March 28 (1994) 39-41.

[5] Brenninkmeiyer C., The use of antimicrobials as growth promoters in poultry, Proc. XX World's Poultry Congress, New Delhi, India, 1996, Vol. II, 119-124.

[6] Broz J., Oldale P., Perrinvoltz A., Effects of Trichoderma viride enzyme complex on performance of broiler chickens receiving pelleted diets, Arch. Geflügelkd. 58 (1994) 182-185.

[7] CEAS Consultants et al., The impact of animal husbandry in the European Community of the use of growth promoters in animal feed, Vol. 1, 2, E.C., Brussels, February 1991, $319 \mathrm{p}$.

[8] Cromwell G.L., Davis G.W., Morrow W.E.M., Primo R.A., Rozeboom D.W., Sims M.D., Stanisiewski E.P., Ho C.H., Efficiency of the antimicrobial compound $\mathrm{U}-82,127$ as a growth promoter for growing-finishing pigs, J. Anim. Sci. 74 (1996) 1284-I 287.

[9] De Craene A., Viaene J., Economic effects of technology in agriculture. Do performance enhancers for animals benefit consumers?, Report, University of Ghent, Fac. Agric. Sciences, Dept. of Agro-Marketing, 1992, 162 p.

[10] Decuypere J.A., Dierick D.A., Vervaeken I.J., Henderickx H.K., Influence of virginiamycin on the digestive physiology in precaecal re-entrant cannulated pigs. Arch. Anim. Nutr. (Berlin) 41 (1991) 373-393.

[11] DuPont H.L., Steele J.H., Use of antimicrobial agents in animals' feeds: Implications in human health, Rev. Infect. Dis. 9 (1987) 447-460.

[12] Elwinger K., Sammanställning över danska och svenska försök med tillväxtstimulerande ämnen (främst zinkbacitracin och payzone) i foder till fjäderfä, Report, Dept. Animal Nutrition and Management, Swed. Univ. Agric. Sciences, Uppsala, Sweden, 1976. 11 p. (in Swedish).

[13] Elwinger K., Engström B., Berndtson E., Fossum O., Teglöf B., Effect of avotan (avoparcin) and maxus (avilamycin) on the caecal growth of $C$. perfringens and the occurrence of necrotic enteritis in broilers, Report Dept. Animal Nutrition and Management, Swed. Univ. Agric. Sciences, Uppsala, Sweden, 1993.

[14] Elwinger K., Engström B., Berndtson E., Fossum O., Waldenstedt L., Effect of growth promoters and coccidiostats on performance and growth of $C$. perfringens in the caeca of broilers, Proc. XX World's Poultry Congress, New Delhi, India, 1996, Vol. II, 219.

[15] Elwinger K., Svensson L., Effects of dietary protein content, litter and drinker type on ammonia emission from broiler houses, J. Agric. Enging. Res. 64 (1996) 197-208.

[16] Fiems L.O., Cottyn B.G., Demeyer D.I., Animal biotechnology and the quality of meat production, Papers presented at OECD Workshop, Melle, Belgium, in: Developments Animal and Veterinary Sciences 25, Elsevier, Amsterdam, 1991 .

[17] Frölich A., Kvarnfors E., Mănsson 1., Simonsson A., Antibiotic additives in sows' diet. Effects on production and intestinal flora, Acta Agric. Scand. 24 (1974) 273-285.

[18] Garland P.W., Range of substances currently available and problems to be addressed for the future, Proc. World's Poultry Sci. Association, 10th Eur. Symp. on Poultry Nutr., Antalya, Turkey, 1995, 203-207.

[19] Gruber F., Einfluss der Di-N-Oxide auf die Futteraufnahme beim Schwein. Dissertation, Ludwig-Maximilians-Univ., München, Germany, 1986.

[20] Hellberg A., Redogörelse för utförd provning av saluförda svinfoderblandningar, Svinskötsel 9 (1965) 233-239 (in Swedish).

[21] Hellberg A., Redogörelse för jämförande försök med olika antibiotika i fodret till slaktsvin, Öllsjö 1967, Svinskötsel 3 (1968) 75-78 (in Swedish).

[22] Hofshagen M., Kaldhusdal M., Barley inclusion and avoparcin supplementation in broiler diets. I. Effects on small intestinal bacterial flora and on performance, Poultry Sci. 71 (1993) 959-969.

[23] Hudd D.L., The addition of antibiotics in feedingstuffs, in: Bogan J., Lees P., Joxall A.T. (Eds.), Pharmacological Basis of Large Animal Medicine, Blackwell Sci. Publications, Oxford, 1983, 107-128. 
[24] Korniewicz A., Klawe A., Kirschke A Paleczek B., Effect of tylosin, bayonox and ridzol on growth and feed utilization of piglets, Roczniki Naukowe Zootechn. 23 (1985) 269-279.

[25] Küther K., Experience with virginiamycin in German broiler production. Proc. Eskalin Broiler Symp, 8 March, London, 1979 , 32-35.

[26] Laming G.E., Growth promoters, in: Future Production and Productivity in Livestock Farming. Developments in Animal and Veterinary Sciences, Elsevier, Amsterdam, 20 (1986) 127-148.

[27] Lange S., Ek E., On putting the argument for banning or tightly controlling the use of antibiotics as feed additives, Proc. World's Poultry Sci. Assoc., 1(th Eur. Symp. Poultry Nutrition, Antalya, Turkey, 1995, I I p.

[28] Langhout D.J., Schutte J.B., Effects of antibiotics and xylanase enzyme preparation alone or in combination on broiler performance, ILOB report Nr. I 94-3895, Wageningen, the Netherlands, 1994, 21 p.

[29] Lindermeyer H., Röhrmoser G., Gradl B., Markenfleischerzeu-gung mit oder ohne Leistungsförderer, Schule und Beratung, 9-10 (1993) $4 \mathrm{p}$.

[30] McCutcheon S.N., The use of growth promoting agents, in: Purchas R.W., Butler-Hogg B.W., Davies A.S. (Eds.), Meat production and Processing, New Zealand Soc. Animal Prod. Occ. Public., 1989, 11, 113-123.

[31] Myers D.J., Speer V.C., Effects of antibiotic and flushing on the performance of sows with short farrowing intervals, J. Anim. Sci. 36 (1973) 1125-1128

[32 Noussiainen J., Suomi K., Comparative observations on selected probiotics and olaquindox used as feed additives for piglets around weaning. 1. Effect on the bacterial metabolites along the intestinal tract, blood values and growth, J. Anim. Physiol. Anim. Nutr. 66 (1991) 212-223.

[33] Richter A., Löscher W., Witte W., Leist ungsförderer mit anti-bakterieller Wirkung: Probleme aus pharmakologisch- toxikologischer und mikrobieller Sicht, Prakt. Tierarzt 77 (1996) 603-624

[34] Robertsson J.A., Lundeheim N., Prohibited use in antibiotics as a feed additive for growth promotion - effects on piglet health and production parameters. Proc. 13th Intern. Pig Vet. Soc. Congr., 282. Bangkok, Thailand, 1994.

[35] Rosen G.D., Antibacterials in poultry and pig nutrition. In: Wallace R.J., Chesson A (Eds.), Biotechnoloy in Animal Feeds and Feeding, VCH Verlagsgesellschaft $\mathrm{mbH}$, Weinheim, Germany, 1995, pp. 143-172.
[36] Rosen G.D., The nutritional effects of tetracyclines in broiler feeds, Proc. XX World"s Poultry Congress, New Delhi, India, 1996. Vol. II, 141-146.

[37] Schneider W., Wirkung des Futterzusatzstoffes Tylan G in der Schweinemast. 1. Mitt. Analyse deutscher Versuchsergebnisse, Schweinezucht und Schweinemast 40 (1992) 3.

[38] Schneider W., Wirkung des Futterzusatztsoffes Tylan G in der Schweinemast. 2. Mitt Leistungsfördernde Effekte, Schweinezucht und Schweinemast 40 (1992) 118-121.

[39] Schurz M., Jeroch H., The influence of antibiotic and enzyme addition to a barley-based ration on fattening performance and some characters of carcass composition and meat quality of broilers, Proc. 9th Eur. Poultry Conf., Darvel, the UK branch of the WPSA, 1994, pp. 441-442.

[40] Schutte J.B., Beelen G.M., Boselli E., Effect of virginiamycin on apparent ileal digestibility of dietary nutrients in adult roosters, Proc 9th Eur. Poultry Conf., 7-12 August 1994. Glasgow, 1994, Vol. 1, 443-444.

[41] Schutte J.B., de Jong J., Boselli E., Interaction effects of virginiamycin and a xylanase enzyme preparation on broiler performance, Proc. 9th Eur. Poultry Conf., 7-12 August 1994, Glasgow, 1994, Vol. 1, 445-446.

[42] Soma J.A., Speer V.C., Effects of PMS and chlortetracycline on the reproductive efficiency of sows, J. Anim. Sci. 41 (1975) $100-105$.

143] SOU, Antimicrobial feed additives, Report from the Commission on Antimicrobial Feed Additves. Fritzes förlag, Stockholm, 1997. $356 \mathrm{p}$.

[44] Speer V.C., Reducing farrowing intervals in sows, Feedstuffs U.S.A. 46 (1974) 20-31.

[45] Tarrago J., Sanz R., Puchal E., Tylosin and virginiamycin as growth promotants in young pigs, Anim. Prod. 26 (1978) 359.

[46] Tidén A., Försök med flavomycin i slaktsvinsfoder. Grupper med och utan förbehandlingsfoder samt jämförelse mellan olika ergotroper, Report Dept. Animal Nutrition and Management, Swed. Univ. Agric. Sciences, Uppsala, Sweden, 1974, 14 p. (in Swedish).

[47] Verbeke W., Viaene J., Experimental impact of using feed additives. Economic implications and legal environment in the Benelux, Report, Univ. Gent, Fac. Agric. and Applied Biol. Sciences, Dept. Agric. Economics, 1996 $43 \mathrm{p}$.

[48] Zivkovic S., Zlatic H., A review of ten years of experience in feed additives in pig diets on large-scale farms in Yugoslavia. Livestock Prod. Sci. 6 (1979) 61-66. 